\title{
Correlation between Insulin-like Growth Factor (IGF)-binding Protein 5 and IGF-I Gene Expression during Brain Development
}

\author{
Carolyn Bondy and Wei-Hua Lee \\ Developmental Endocrinology Branch, NICHD, NIH, Bethesda, Maryland 20892
}

Insulin-like growth factor (IGF)-binding proteins (IGFBPs) potently modulate the interactions of IGF-I and -II with the IGF-I receptor. Previous studies have shown that IGFBP2 gene expression is localized in astroglia, where it is anatomically and temporally coordinated with neuronal IGF-I expression during postnatal brain development. The present study shows that IGFBP5 gene expression is also highly abundant during brain development and also demonstrates significant spatiotemporal correlation with IGF-I, but exhibits a neuroanatomical distribution that is entirely distinct from IGFBP2. IGFBP5 and IGF-I mRNAs are synchronously coexpressed in principal neurons of sensory relay systems, including the olfactory bulb, medial and dorsal lateral geniculate bodies, and ventral tier, cochlear, lemniscal, and vestibular nuclei. They are also transiently coexpressed in principal neurons of the anterodorsal nucleus, but IGF-I mRNA disappears from this structure shortly after birth, while IGFBP5 mRNA remains highly abundant here in the adult.

IGFBP5 and IGF-I gene expression demonstrate a temporally coordinated laminar association in the developing cerebellar cortex and hippocampal formation. IGF-I mRNA is concentrated in Purkinje cells, while IGFBP5 mRNA is localized in the external germinal zone in the developing cerebellar cortex. IGFBP5 mRNA is transiently expressed in the retrosplenial and cingulate cortex, subiculum, Ammon's horn, and amygdala, while IGF-I mRNA is contemporaneously localized in large interneurons distributed throughout the hippocampal formation. IGFBP5 mRNA is localized in the lateral ventricular germinal zone at birth and remains in the subventricular zone into maturity. It is also detected in forebrain white matter tracts and olfactory nerve from the second week after birth into maturity.

Thus IGFBP5, in addition to IGFBP2, may be a significant determinant of IGF action in the brain. Colocalization in some sites and paralocalization with IGF-I in other sites suggests the potential for autocrine and paracrine interaction between the binding protein and IGF-I in different settings. Arguments are advanced suggesting a role for IGFBPs in the targeting

Received Feb. 19, 1993; revised May 21, 1993; accepted June 15, 1993

We are grateful to Peter Rotwein for supplying us with the IGFBP5 clone prior to publication and to Ricardo Dreyfuss and John Ward for expert photography. W.-H.L. was a Pharmacology Research Associate of the National Institute of General Medical Sciences during the time of this study.

Correspondence should be addressed to C. A. Bondy, NIH, Building 10, Room 10N262, Bethesda, MD 20892.

a Present address: University of Indiana Medical School, Indianapolis, IN. Copyright (C) 1993 Society for Neuroscience $0270-6474 / 93 / 135092-13 \$ 05.00 / 0$ of IGF action to specific cell addresses during brain development.

[Key words: IGF-I, IGF-I receptor, mRNA, cerebellum, germinal zone]

Insulin-like growth factors I and II (IGF-I and -II) are anabolic peptides that are present in the circulation and that are also synthesized locally in a variety of tissues, including the brain. IGF-I demonstrates a highly distinctive pattern of gene expression during brain development (Bondy, 1991). It is concentrated in the large principal neurons of sensory and cerebellar projection systems, with peak expression during a late stage of development characterized by growth of neuronal soma and processes. IGF-I's actions are mediated by the IGF-I receptor, which is a membrane-bound, ligand-activated tyrosine kinase homologous to the insulin receptor. This receptor is widely expressed throughout the brain, as revealed by ligand-binding studies (Sara et al., 1982; Bohannon et al., 1988; Lesniak et al., 1988; Werther et al., 1989) and in situ hybridization (Marks et al., 1991; Bondy et al., 1992a,b). It is particularly abundant in the brain regions and cells where IGF-I is synthesized, suggesting a local autocrine or paracrine mode of action for neuronal IGF-I (Bondy et al., 1992a). This view is supported by the localization of IGF-I immunoreactivity in the immediate vicinity of cellular sites of synthesis (Andersson et al., 1988). The function of IGF-I synthesized by these neurons is not known, but based upon significant parallelism between the pattern of IGF-I receptor distribution and patterns of brain metabolic activity as revealed by glucose uptake and protein synthesis, it has been suggested that IGF-I may be an endogenous regulator of neural metabolism (Bondy and Lee, 1993).

In the circulation and bodily fluids, the IGFs are complexed with high-affinity IGF-binding proteins (IGFBPs), of which six structurally and genetically related species have been characterized (reviewed by Clemmons, 1990; Rosenfeld et al., 1990; Rechler and Brown, 1992). These IGFBPs bind IGFs with significantly greater affinity than does the IGF-I receptor and are synthesized in different tissues in concert with local IGF-I or -II synthesis, where they are thought to modulate IGF action in the autocrine or paracrine setting. A number of different IGFBPs have been found in cultured neural tissues and cerebrospinal fluid (Haselbacher and Humbel, 1982; Han et al., 1988; Ocrant et al., 1990; Olson et al., 1991; Roghani et al., 1991). We have recently shown that IGFBP2 gene expression is concentrated in astroglia in temporal and anatomical contiguity with neuronal IGF-I gene expression (Lee et al., 1992b, 1993). For example, in the cerebellar cortex, IGFBP2 mRNA is localized in Bergmann radial glia adjacent to IGF-I-synthe- 
sizing Purkinje cells (Lee et al., 1992b). IGFBP2 mRNA is also abundant in the choroid plexus and meninges in association with IGF-II (Tseng et al., 1989; Wood et al., 1990; Lee et al., 1992a,b, 1993). The present work extends our study of IGF system gene expression during rat brain development to IGFBP5. In this study, serial brain sections from the time of birth through postnatal day 60 (P60) were hybridized to cRNA probes for IGF-I, IGFBP2, IGFBP5, and the IGF-I receptor in order to delineate neuroanatomical patterns of IGFBP5 gene expression and their spatiotemporal relationship to the other elements of the IGF constellation.

\section{Materials and Methods}

Timed-pregnant Sprague-Dawley rats were obtained from Taconic Farms (Germantown, NY). All animals were maintained in accordance with NIH guidelines for the care and use of laboratory animals, provided with standard rat chow and water ad libitum, and placed on a 12:12 hr light/dark cycle. All pups were born in house and kept with the mother until death by decapitation following carbon dioxide anesthesia. Three to five brains were evaluated at each of the following time points: the day of birth (P1), P5, P12, and P20. One or two brains were evaluated at $P 40, P 60$, and $P 90$. All brains were immediately removed and snap frozen in isopentane and then stored at $-70^{\circ} \mathrm{C}$. Coronal sections of 10 $\mu \mathrm{m}$ thickness were cut through the entire rostral-caudal extent of the brain at $-15^{\circ} \mathrm{C}$, thaw-mounted onto poly-L-lysine-coated slides, and stored at $-70^{\circ} \mathrm{C}$ until hybridization.

Rat IGF-I, IGF-I receptor, and IGFBP-2, and murine IGFBP5 cDNA clones were used for the synthesis of cRNA probes, and each has been described in detail previously (Zhou and Bondy, 1993). ${ }^{35}$ S-labeled antisense and sense riboprobes were synthesized in $10 \mu \mathrm{l}$ of reaction mixture containing $100 \mu \mathrm{Ci}$ each of ${ }^{35} \mathrm{~S}-\mathrm{CTP}$ and ${ }^{35} \mathrm{~S}-\mathrm{UTP}$ (New England Nuclear), $10 \mathrm{~mm} \mathrm{NaCl}, 6 \mathrm{~mm} \mathrm{MgCl}, 40 \mathrm{~mm}$ Tris (pH 7.5), $2 \mathrm{~mm}$ spermidine, $10 \mathrm{~mm}$ dithiothreitol (DTT), $500 \mu \mathrm{M}$ each unlabeled ATP and GTP, $25 \mu \mathrm{M}$ each unlabeled UTP and CTP, $1 \mu \mathrm{g}$ of linearized template, $15 \mathrm{U}$ of the appropriate polymerase (Bethesda Research Labs) and $15 \mathrm{U}$ of RNasin (Promega). The reaction was incubated at $42^{\circ} \mathrm{C}$. for $60 \mathrm{~min}$, after which the DNA template was removed by digestion with DNase I. Average specific activity of probes generated by this protocol was $2.5 \times 10^{8} \mathrm{dpm} / \mu \mathrm{g}$.

Prior to hybridization, tissue sections were warmed to $25^{\circ} \mathrm{C}$, fixed in $4 \%$ formaldehyde, and acetylated in $0.25 \%$ acetic anhydride, $0.1 \mathrm{M}$ triethanolamine hydrochloride, $0.9 \% \mathrm{NaCl}$. Tissue was dehydrated through an ethanol gradient, delipidated in chloroform, rehydrated, and air dried. ${ }^{35} \mathrm{~S}$-labeled $\mathrm{cRNA}$ probes were added to fresh hybridization buffer $\left(10^{7} \mathrm{cpm} / \mathrm{ml}\right)$ composed of $50 \%$ formamide, $0.3 \mathrm{M} \mathrm{NaCl}, 20 \mathrm{mM}$ Tris $\mathrm{HCl}(\mathrm{pH} 8$ ), $5 \mathrm{~mm}$ EDTA, $500 \mu \mathrm{g}$ of tRNA $/ \mathrm{ml}, 10 \%$ dextran sulfate, $10 \mathrm{~mm}$ DTT, and $0.02 \%$ each of BSA, ficoll, and polyvinylpyrollidone. Hybridization buffer was added to sections, which were then covered with glass coverslips and placed in humidified chambers overnight (14 $\mathrm{hr}$ ) at $55^{\circ} \mathrm{C}$. Slides were washed several times in $4 \times$ saline-sodium citrate (SSC) to remove coverslips and hybridization buffer, dehydrated, and immersed in $0.3 \mathrm{M} \mathrm{NaCl}, 50 \%$ formamide, $20 \mathrm{~mm}$ Tris $\mathrm{HCl}, 1 \mathrm{~mm}$ EDTA at $60^{\circ} \mathrm{C}$ for $15 \mathrm{~min}$. Sections were then treated with RNase A $\left(20 \mu \mathrm{g} / \mathrm{ml}\right.$; Boehringer Mannheim, Indianapolis, IN) for $30 \mathrm{~min}$ at $37^{\circ} \mathrm{C}$ and passed through graded salt solutions, followed by a $15 \mathrm{~min}$ wash in $0.1 \times \mathrm{SSC}$ at $50^{\circ} \mathrm{C}$. Slides were dehydrated, air dried, and apposed to Hyperfilm-beta Max (Amersham) for 1-5 d, and then dipped in Kodak NTB3 nuclear emulsion, stored with desiccant at $4^{\circ} \mathrm{C}$ for $3-15$ d, developed, and stained with cresyl violet or hematoxylin and eosin for microscopic evaluation. Each cRNA probe produced a specific and different pattern of hybridization in brain tissues. The level of nonspecific signal, as determined by hybridization of parallel tissue sections with a sense probe synthesized from the IGFR-I clone, was minimal.

\section{Results}

\section{Olfactory bulb}

Figure 1 compares IGFBP5, IGF-I, and IGFBP2 gene expression in the olfactory bulb during postnatal development. IGF-I and IGFBP5 mRNAs are first detected in the olfactory bulb mitral cell layer at embryonic day 15 (E15; not shown). IGFBP5 and IGF-I mRNAs are colocalized in mitral projection neurons, while IGF-I but not IGFBP5 mRNA is also localized in tufted cells (seen as multiple concentric rings of hybridization vs. the single ring representing the mitral cell layer for IGFBP5 in Fig. 1). IGFBP2 mRNA is diffusely expressed throughout the olfactory bulb, although it is more heavily concentrated in the mitral cell layer. Previous studies have shown that IGFBP2 mRNA is localized in astrocytes, and is particularly abundant in those adjacent to IGF-I-expressing projection neurons (Lee et al., $1992 b, 1993$ ). During postnatal maturation of the olfactory bulb, IGFBP5 gene expression exhibits significant changes in intensity and in cellular distribution while IGF-I remains essentially unchanged (Fig. 1). IGFBP5 mRNA levels decrease in the mitral cell layer, and increase in the olfactory nerve layer and in the granule cell layer. The increased levels of IGFBP5 mRNA in glial cells of the olfactory nerve are particularly striking.

\section{Thalamus}

Figure 2 compares IGFBP5, IGF-I, anad IGFBP2 gene expression in the anterior thalamus on P12. Most notably, IGFBP5 and IGF-I mRNAs are colocalized in the anterodorsal nucleus. In terms of other components of the anterior thalamic nuclear complex, IGFBP5 mRNA is present at low levels in the anteroventral nucleus, where IGF-I mRNA is not detected, while IGF-I mRNA is concentrated in the mediolateral nucleus, where IGFBP5 is not detected (Fig. 2). IGFBP5 gene expression continues to be highly abundant in the anterodorsal nucleus at the latest developmental stage examined (P60), while IGF-I gene expression is barely detectable in the anterior thalamus after the third postnatal week. IGFBP5 mRNA is also localized in the suprachiasmatic nucleus from P12 (Fig. $2 A$ ) into adulthood. IGFBP2 $\mathrm{mRNA}$ is concentrated in the anterior thalamic nuclear complex, but is more diffusely expressed than IGF-I or IGFBP5, as is typical of the pattern of IGFBP2 expression in astroglia. IGFBP5 mRNA is also localized in the subventricular zone of the lateral ventricles, and to a lesser extent in the white matter tracts flanking the ventricles (Fig. $2 A$ ).

IGFBP5 and IGF-I mRNAs are detected in the ventral tier nuclei from approximately E18 (not shown). Figure 3 shows the postnatal course of IGFBP5 gene expression in these nuclei and compares IGFBP5 with IGF-I, IGFBP2, and the IGF-I receptor at P12. IGFBP5 mRNA levels remain high in the ventroposterolateral and ventroposteromedial nuclei and dorsolateral geniculate from birth through $P 12$, but are greatly reduced by P60 (Fig. $3 A-C$ ). IGFBP5 and IGF-I mRNAs are colocalized in the projection neurons of the ventral tier and dorsolateral geniculate nuclei (Figs. 3, 4A-D). IGFBP2 mRNA is concentrated in these same centers, but is localized in astroglia (Figs. $3 D, 4 E, F)$. IGFBP5, IGF-I, and IGFBP2 gene expression exhibit the same pattern in the development of the medial geniculate nucleus. IGFBP5 mRNA localization in this auditory projection center is demonstrated in Figure 5, while IGF-I and IGFBP2 have been previously described (Bondy, 1991; Lee et al., 1993). The temporal pattern of IGFBP5 gene expression in all of these sensory projection centers parallels that of IGF-I and IGFBP2 (Bondy, 1991; Lee et al., 1992b, 1993; present results).

\section{Hippocampal formation}

IGFBP5 gene expression in the developing hippocampal formation is seen in Figures 3 and 5. There is transient perinatal expression in neurons of the subiculum, Ammon's horn, amygdaloid complex, and retrosplenial cortex. IGFBP5 gene expres- 


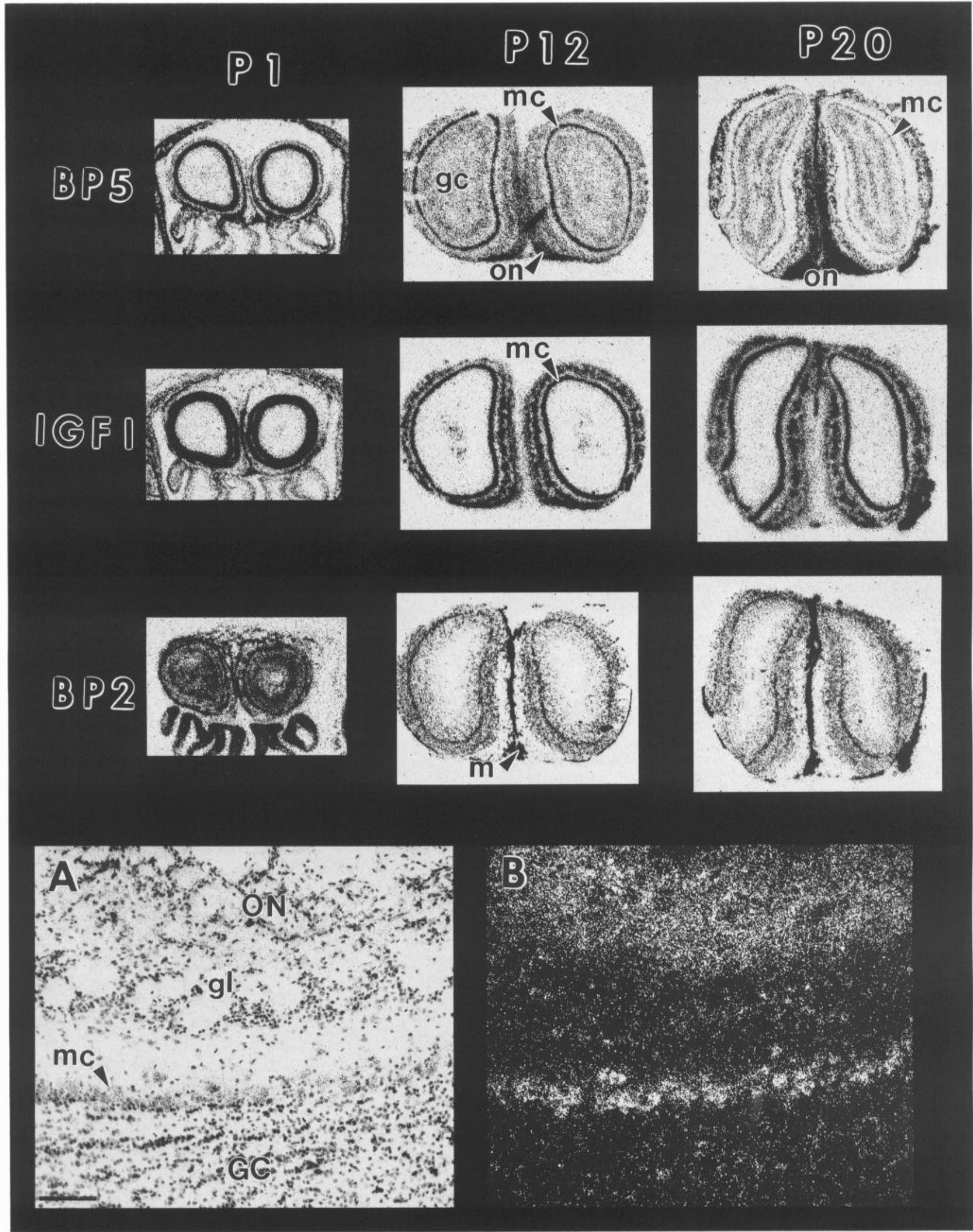

Figure 1. Comparison of IGFBP5, IGF-I, and IGFBP2 gene expression in olfactory bulb development. Serial, coronal sections from rat olfactory bulbs at P1, P12, and P20 were hybridized to the respective cRNA probes and the results are shown in film autoradiographs arrayed in rows across the upper part of the figure. Panels $A$ and $B$ at the bottom of the figure are paired bright- and dark-field photomicrographs showing IGFBP5 mRNA in a section from a P12 olfactory bulb. In the dark-field illumination, hybridization appears as white grains. For abbreviations, see Appendix. Scale bar, $100 \mu \mathrm{m}$ for $A$ and $B$. 


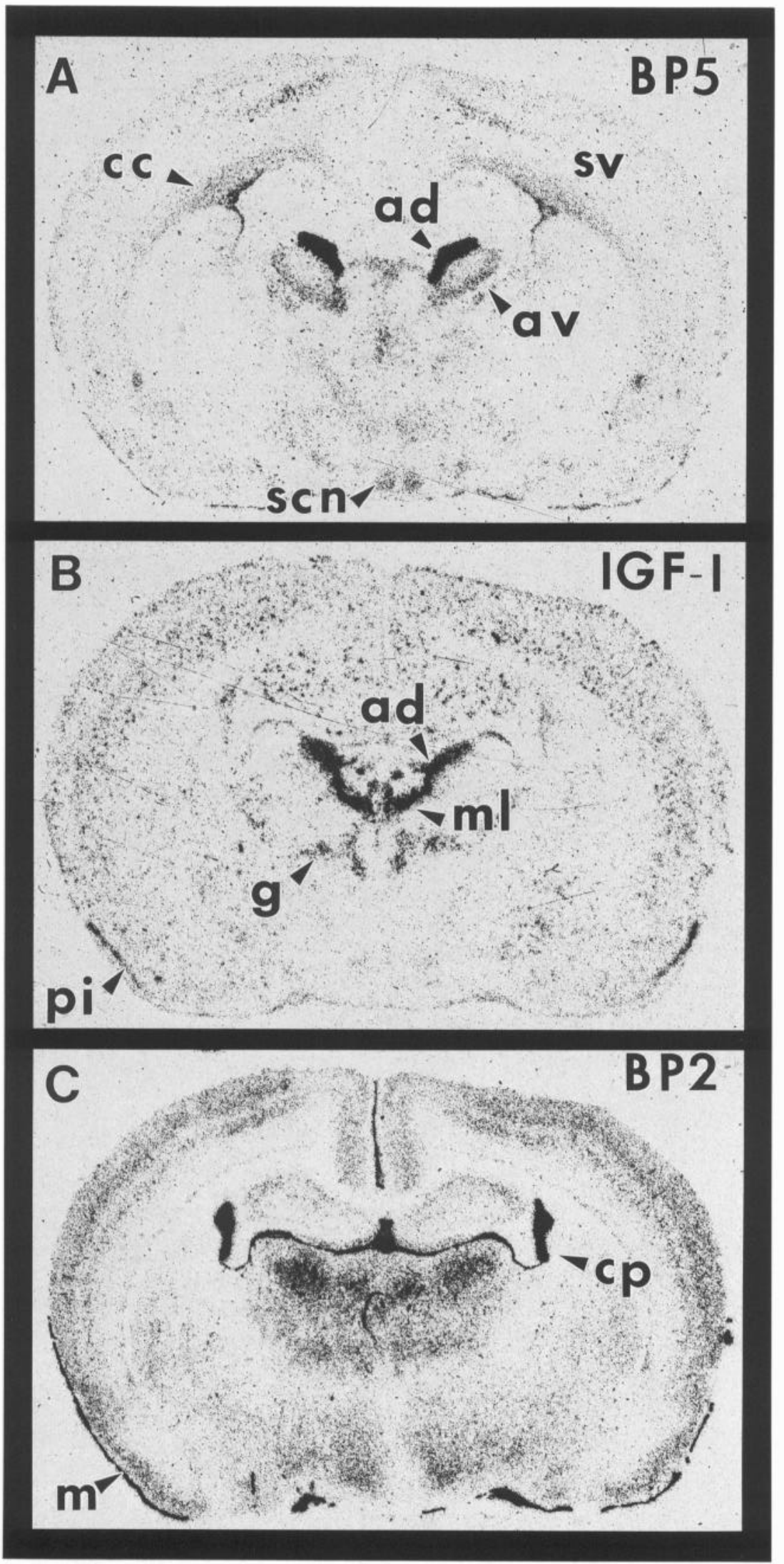

Figure 2. Comparison of IGFBP5 $(A)$, IGF-I $(B)$, and IGFBP2 $(C)$ gene expression in the anterior thalamus on P12. These are film autoradiographs of serial coronal section hybridized to the different cRNA probes. For abbreviations, see Appendix. 

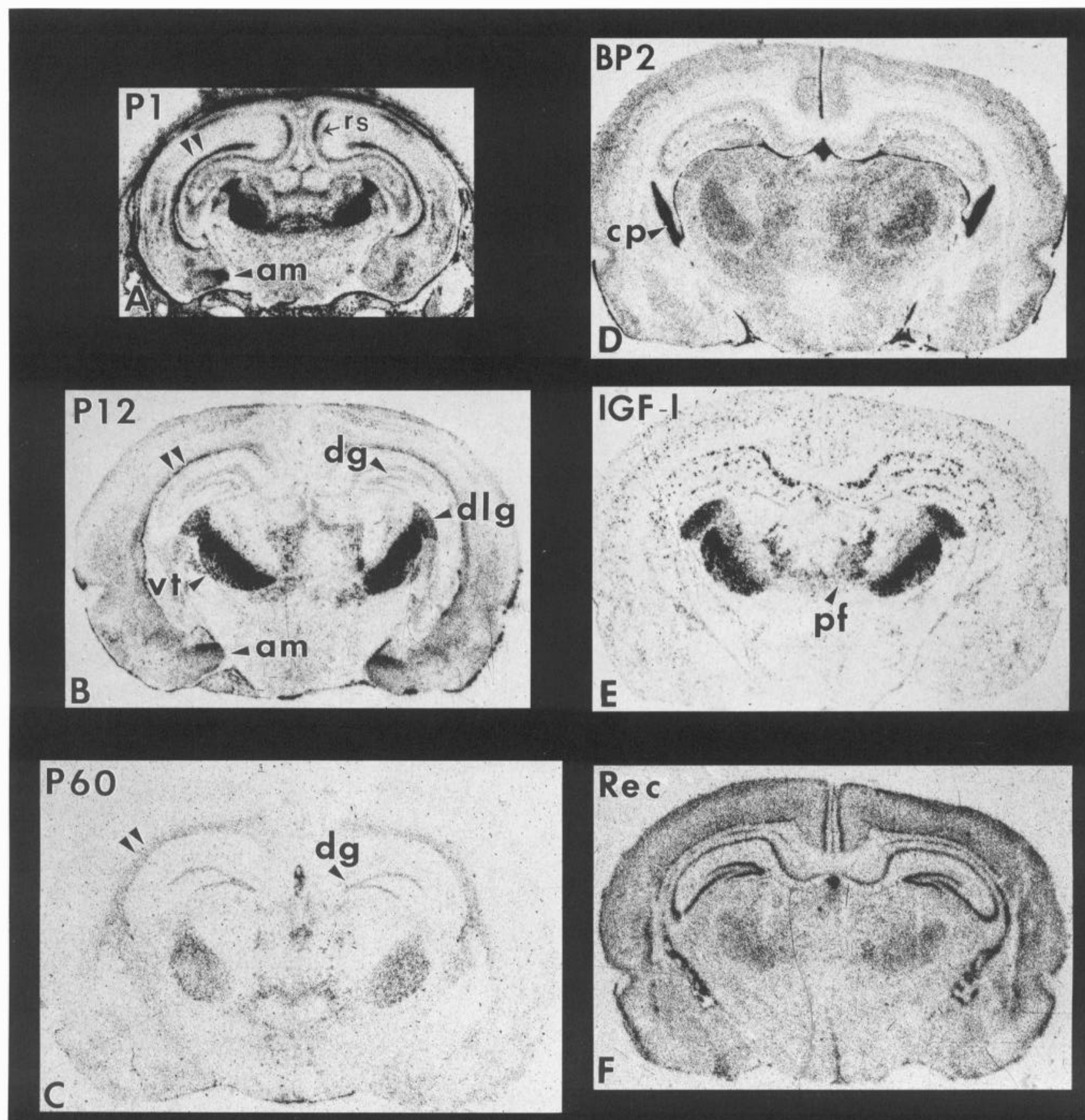

Figure 3. IGFBP5 gene expression in ventral tier thalamic nuclei during postnatal brain development shown in film autoradiographs of anatomically matched coronal sections $(A-C)$. These sections were hybridized, washed, and exposed together to allow comparison of signal across the different developmental stages. Patterns of IGFBP2, IGF-I, and IGF-I receptor gene expression in serial sections to that shown for IGFBP5 at P12 (B) are shown on the right $(D-F)$. Double arrowheads, subventricular zone of the lateral ventricles and developing subcortical white matter tracts. For abbreviations, see Appendix.

sion declines very soon after birth in all these structures except for the ventral subiculum, where it is localized in an irregular array of pyramidal cells (Fig. $6 G$ ). IGFBP5 gene expression appears in the granule cells of the dentate gyrus after the second postnatal week, during the time when it is declining elsewhere (Figs. 3, 5). IGF-I mRNA is localized in large interneurons dispersed throughout the hippocampus and IGFBP2 in hippocampal astroglial (Lee et al., 1993).

\section{Cerebellum}

From just before birth (E20), IGFBP5 mRNA is localized in a number of small (non-Purkinje) cells dispersed through the cerebellar anlage, and in cells in the external germinal zone (Fig. $6 A$ ). At E20 and P1, IGFBP5 mRNA is present in the full thickness of the external zone (Fig. $6 A-C$ ). From P5 to P12, IGFBP5 mRNA is detected in cells situated in the most super- 

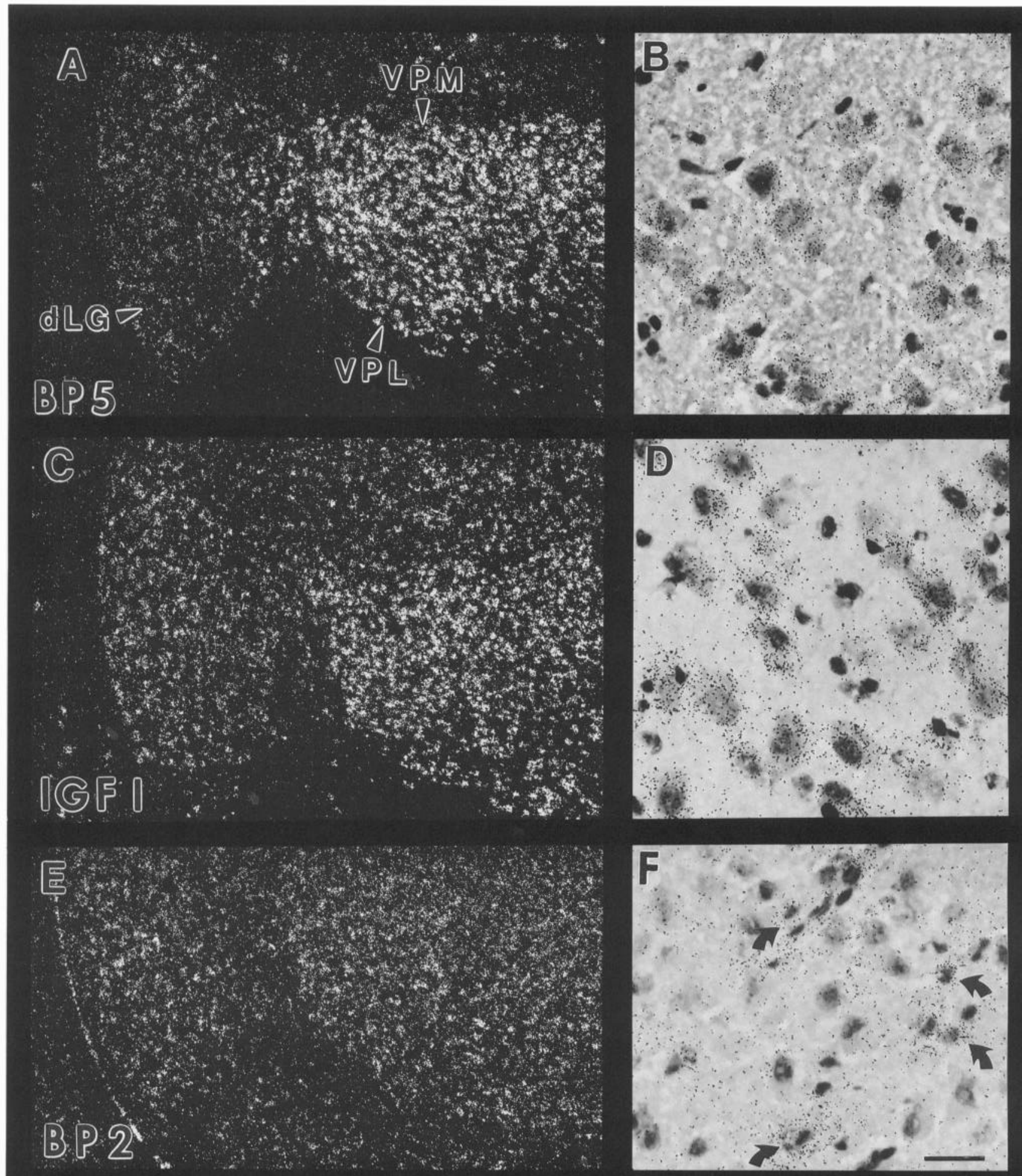

Figure 4. Comparison of IGFBP5 $(A, B)$, IGF-I $(C, D)$, and IGFBP2 $(E, F)$ mRNA expression in the ventral tier and dorsolateral geniculate nuclei on P12. Dark-field, low-power micrographs are shown on the left, and high-power, bright-field micrographs on the right. The high-magnification micrographs show a region in the ventroposteromedial nuclei. Arrows in $F$ point to small, IGFBP2 mRNA-containing glial cells. For abbreviations, see Appendix. Scale bar, $100 \mu \mathrm{m}$ for $A, C$, and $E ; 20 \mu \mathrm{m}$ for $B, D$, and $F$.

ficial zone of the external granule cell layer, but not in the deeper zone where granule cells are verging on the molecular layer (Fig. $6 D, E)$. During this period, IGFBP5 mRNA remains detectable in the small nondescript cells scattered throughout the cerebellar cortex. By P20, the external granule cell layer is entirely depleted and IGFBP5 mRNA is greatly reduced throughout the cerebellar cortex. IGFBP5 mRNA appears in granule cells of the internal granule cell layer during the third week after birth (not shown), 
Figure 5. IGFBP5 gene expression in the medial geniculate nucleus and ventral hippocampal formation during postnatal brain development. These anatomically matched coronal sections were hybridized, washed, and exposed together. The $P 12$ section has a pituitary gland attached to the base of the brain. For abbreviations, see Appendix.

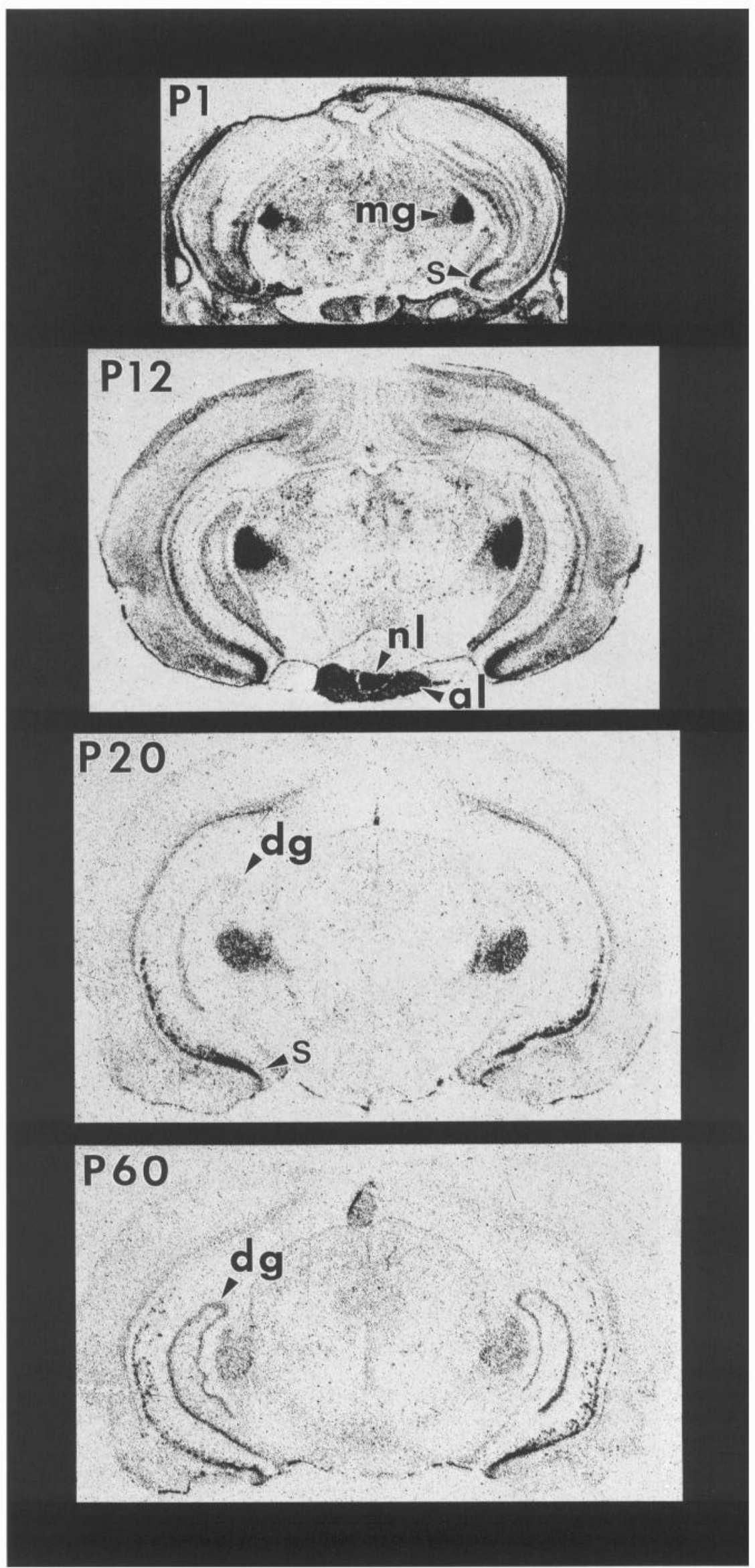



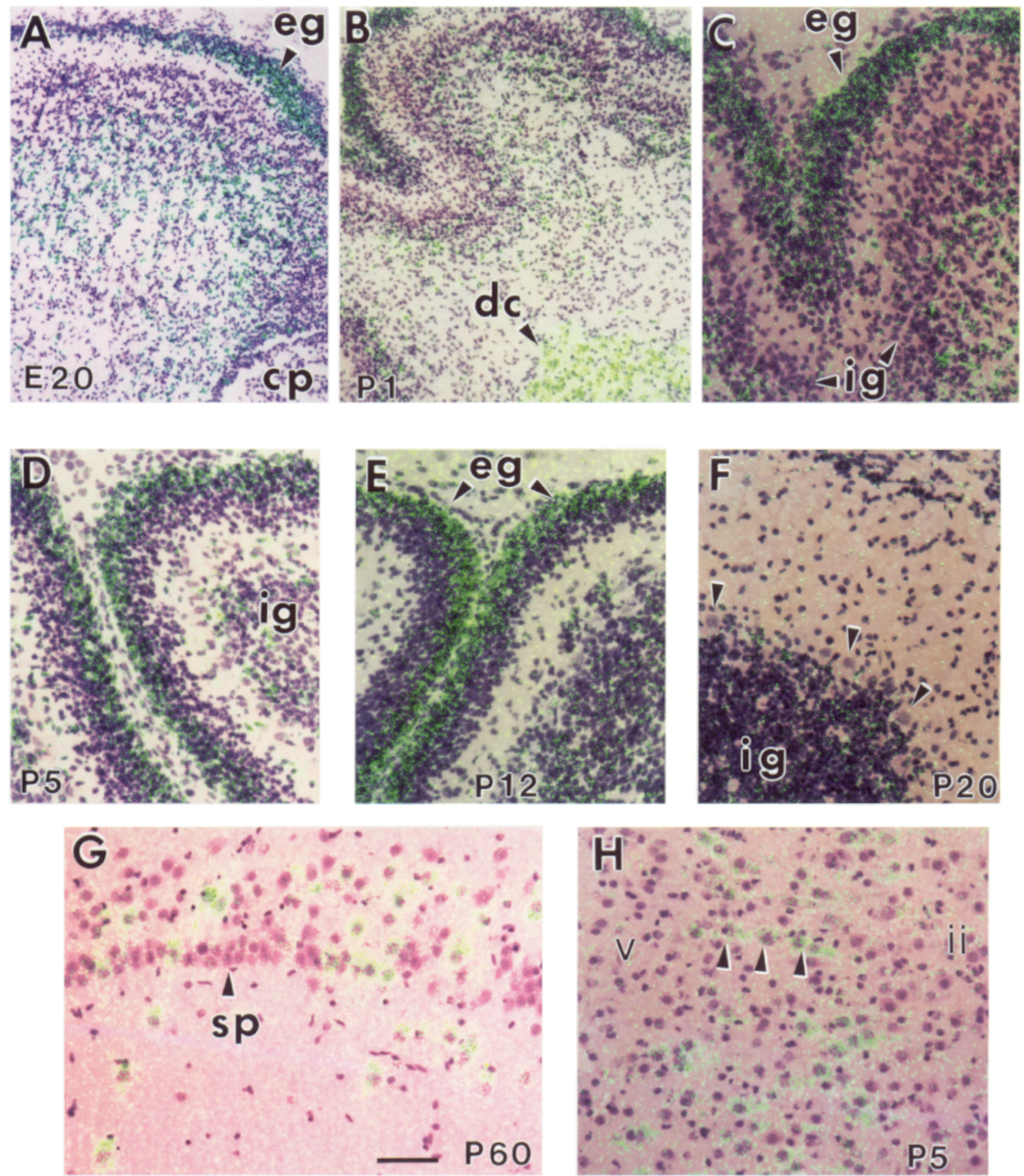

Figure 6. IGFBP5 mRNA in the developing cerebellum (E20-P20,A-F) and in large neurons of the adult ventral subiculum $(G)$ and $\mathrm{P} 5$ neocortex $(H)$. A shows a sagittal section through the cerebellar anlage from an E20 fetus. The choroid plexus of the fourth ventricle is at the lower right. $B$ shows a sagittal section from a P1 cerebellum, photographed at the same magnification as $A$, and $C$ shows the same P1 section at a higher magnification. All the photomicrographs in this figure are double-exposure bright and dark field taken with a green filter, so the hybridization signal appears as green grains. For abbreviations, see Appendix. Single arrowheads $(F)$ point to Purkinje cells; triple arrowheads $(H)$ indicate a vertical column or chain of IGFBP5 mRNA-expressing neurons spanning cortical layers 3 and 4 (layers 2 and 5 are labeled in $H$ for reference). Scale bar: $100 \mu \mathrm{m}$ for $A$ and $B ; 50 \mu \mathrm{m}$ for $C-F ; 20 \mu \mathrm{m}$ for $G$ and $H$. 


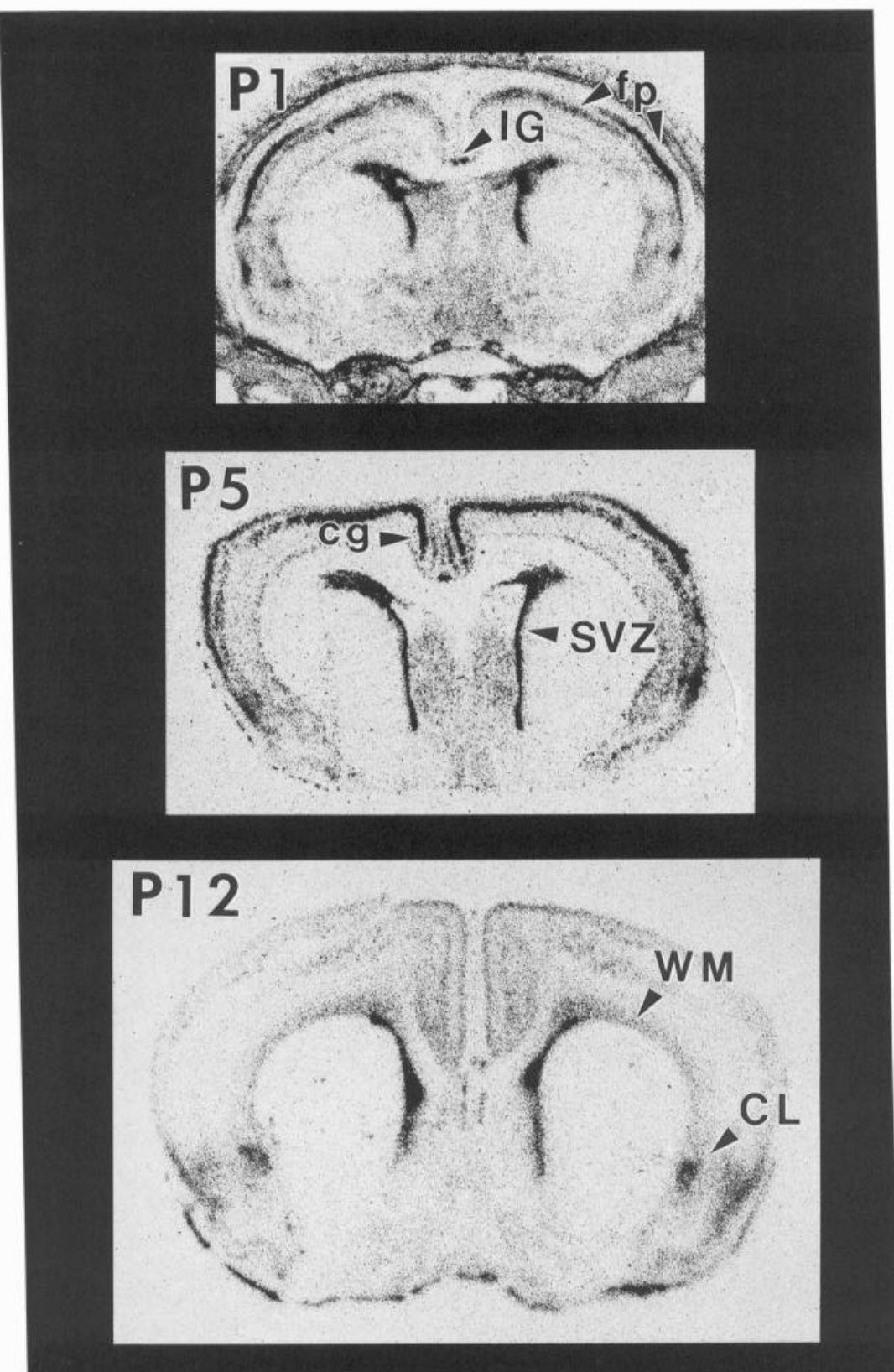

P20

Figure 7. IGFBP5 gene expression in the neocortex and subventricular zone of the anterior lateral ventricles during postnatal brain development. For abbreviations, see Appendix. 


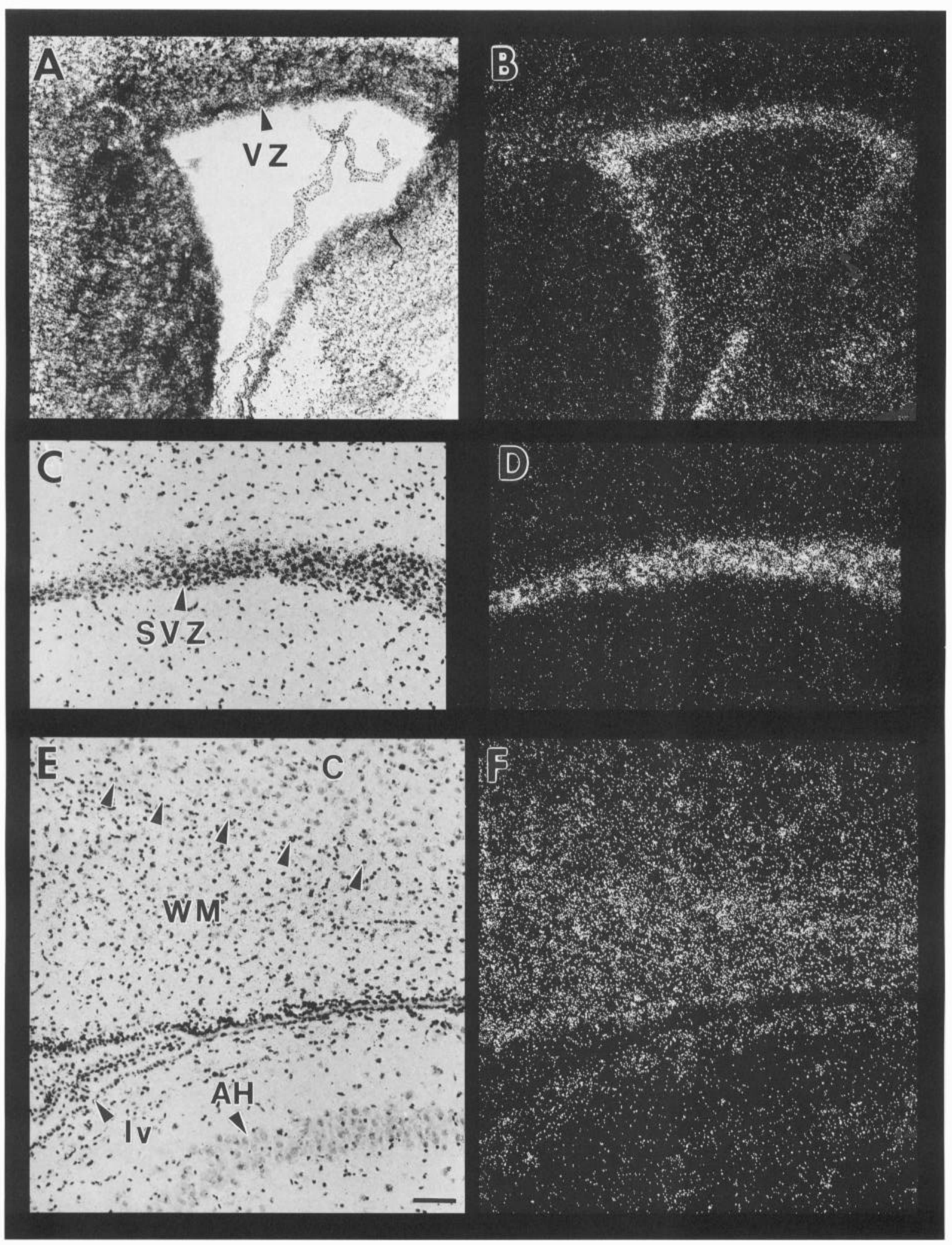

Figure 8. Expression of IGFBP5 mRNA in the region of the lateral ventricles from the time of birth $(A, B)$ through $\mathrm{P} 20(C-F) . A$ and $B$ are paired bright- and dark-field micrographs of a sagittal section through the lateral ventricle on P1. IGFBP5 mRNA is concentrated in the germinal cells of the ventricular zone $(V Z)$ immediately adjacent to the ventricle. $C$ and $D$ show an extension of the subventricular zone $(S V Z)$ from the anterior horn of the lateral ventricle on P20. $E$ and $F$ show IGFBP5 mRNA concentrated in the subcortical white matter tract on P20. For other abbreviations, see Appendix. Arrowheads indicate the border of the parietal cortex. Scale bar, $100 \mu \mathrm{m}$. 


\begin{tabular}{|c|c|c|c|c|c|}
\hline Structure & Pl & P5 & P12 & P20 & P40 \\
\hline \multicolumn{6}{|l|}{ Olfactory bulb } \\
\hline $\mathrm{mc}$ & +++ & ++ & + & + & + \\
\hline Granule cell layer & - & - & + & ++ & ++ \\
\hline Olfactory nucleus & + & + & $t+$ & +++ & +++ \\
\hline \multicolumn{6}{|l|}{ Thalamus } \\
\hline ad & +++ & $+t+$ & ++ & $+t+$ & +++ \\
\hline av & ++ & ++ & ++ & + & + \\
\hline $\operatorname{scn}$ & ++ & ++ & ++ & $++t$ & +++ \\
\hline VPM/VPL & $++t$ & +++ & +++ & ++ & + \\
\hline dlg & ++ & +++ & ++ & ++ & + \\
\hline $\mathrm{mg}$ & ++ & +++ & +++ & ++ & + \\
\hline \multicolumn{6}{|l|}{ Hippocampus } \\
\hline IG & ++ & + & - & - & - \\
\hline DSub & ++ & + & - & - & - \\
\hline AH & ++ & ++ & + & - & - \\
\hline VSub & +++ & +++ & $+t+$ & ++ & ++ \\
\hline Dentate GC & - & - & + & ++ & ++ \\
\hline \multicolumn{6}{|l|}{ Mid/hindbrain } \\
\hline Pons & ++ & $+t$ & $t+$ & ++ & ++ \\
\hline In Col & ++ & $+t$ & + & - & - \\
\hline $\mathrm{SO}$ & 11 & ++ & 1 & + & + \\
\hline $\mathrm{IO}$ & ++ & $t+$ & ++ & + & + \\
\hline V'Tg & $+t$ & $+t$ & ++ & + & + \\
\hline $\mathrm{mvb}$ & ++ & ++ & ++ & + & - \\
\hline dco & ++ & ++ & + & - & - \\
\hline den & ++ & +++ & ++ & + & - \\
\hline
\end{tabular}

For abbreviations, see Appendix.

demonstrating a delayed time course and low level of expression similar to that seen in the granule cells of the olfactory bulb and dentate gyrus. IGFBP5 mRNA is abundant in large neurons populating the deep cerebellar nuclei from Pl (Fig. 6B) through P12. IGF-I mRNA is also concentrated in these deep cerebellar neurons (Bondy, 1991).

\section{Isocortex}

IGFBP5 gene expression demonstrates a laminar pattern in some regions of the frontoparietal cortex during the first postnatal week (Figs. 6H,7). It is localized in relatively large, pyramidallike cells that span layers $3-5$, and in many areas the cells appear to be vertically aligned (Fig. $6 H$ ). There is no apparent relationship between IGFBP5 and IGF-I expression in the isocortex. IGF-I mRNA is contained in large interneurons that are widely distributed throughout all regions and layers (Bondy, 1991; Lee et al., 1993). Thesc cells are so large and the mRNA so abundant that the IGF-I hybridization signal from individual cells is visible on film autoradiographs (Figs. $2 B, 3 E$ ).

\section{Other sites}

At the time of birth, IGFBP5 mRNA is highly abundant in the germinal zone of the lateral ventricles (Figs. $2 A, 3 A, 7,8$ ). After $\mathrm{P} 12$, the ventricular germinal zone has disappeared everywhere except in the anterior horn of the lateral ventricle, where the subventricular germinal zone persists and where IGFBP5 gene expression remains high into adult life (Figs. 7, 8). Low levels of IGFBP5 mRNA are present in subcortical white matter tracts from P12 (Figs. 3A-C, 7, 8). IGFBP5 mRNA was also detected in brainstem reticular and tegmental nuclei, but these structures were not studied systematically. The time course and neuroanatomical distribution of IGFBP5 gene expression during rat brain development are summarized in Table 1.

\section{Discussion}

Among the six high-affinity IGFBPs that have been identified to date, IGFBP2 and IGFBP5 are most prominently expressed in the brain and both show peak gene expression in the brain parenchyma coinciding with peak IGF-I gene expression, that is, during the first 2 postnatal weeks. However, these two IGFbinding proteins demonstrate distinct neuroanatomical patterns and relationships to neuronal IGF-I gene expression. IGFBP2 mRNA is concentrated in astroglial cells adjacent to IGF-Iexpressing projection neurons in the retina, cerebellar cortex, and sensory relay centers (Lee et al., 1992b, 1993). IGFBP5 mRNA, as shown in the present study, is colocalized with IGF-I in the projection neurons of sensory relay systems, and is paralocalized in hippocampal and cerebellar laminar neurons. In addition, IGFBP5 mRNA is expressed in neuroepithelial germinal zones and forebrain white matter tracts in apparent dissociation from local IGF-I production.

The IGFBPs are soluble proteins that are constitutively secreted in tandem with their synthesis, as are IGF-I and -II. IGFBPs synthesized and secreted from the liver bind IGFs in the systemic circulation and serve to prolong IGF half-life. Certain IGFBPs may facilitate the transfer of IGFs from the circulation into tissue compartments (Bar, 1990). The role of IGFBPs that are synthesized in specific tissues in conjunction with local IGF synthesis is not understood at present. A number of factors determine whether IGFBPs will have an inhibitory or facilitory impact upon IGF interaction with the IGF-I receptor in vitro. These conditioning factors include the phosphorylation and multimerization state of the IGFBP, the association of IGFBP with the cell surface or extracellular matrices, and the relative amounts of IGF versus IGFBP (reviewed in Clemmons, 1990). How these factors might pertain to the in vivo situation where IGF and IGFBP are synthesized and secreted by the same or neighboring cells has not been ascertained.

IGFBP5 mRNA is coexpressed with IGF-I in principal neurons of most but not all major sensory projection centers, that is, mitral cells, medial and dorsolateral geniculate bodies, and cochlear, vestibular, superior olivary, and ventral tier nuclei. IGFBP5 mRNA is not detected, however, in the piriform cortex or anterior pretectal nucleus, while IGF-I mRNA is abundant in these sites (Bondy, 1991). IGF-I gene expression also tracks cerebellar relay stations, including inferior olives, Purkinje cells, and deep cerebellar and red nuclei but not the pontine nuclei, while IGFBP5 mRNA is detected in the inferior olivary and deep cerebellar and pontine nuclei, but not Purkinje cells or red nucleus. During the analysis of the pattern of IGF-I gene expression during postnatal brain development, it was noted that there were significant omissions or gaps in the chain of expression in these functionally related projection systems, for example, the pontine nuclei, in the case of cerebellar transmission. Now it is found that IGFBP5 fills in these missing links. The significance of this patchwork pattern of IGF system expression in sensory and cerebellar projection networks is not understood at present.

IGFBP5 gene expression traces nearly all elements of the hippocampal formation as well as many components of the limbic system during postnatal brain development. It is expressed in pyramidal cells of Ammon's horn during the first 
weeks after birth, at which time IGF-I mRNA is localized in large interneurons in the strata flanking the pyramidal layer (I ee et al., 1993). IGFBP5 mRNA is localized in both the dorsal and ventral subiculum, and is especially prominent in the latter, where it remains relatively abundant in the adult. It is also localized in the amygdala, retrospenial and cingular cortex, and anterodorsal nucleus of the thalamus - coexpressed with IGF-I in the latter. IGF-I but not IGFBP5 mRNA is concentrated in septal and diagonal band nuclei (Bondy, 1991), and both are expressed in the olfactory system. Continued high levels of IGF-I and IGFBP5 gene expression are present in the olfactory system in the adult, and IGFBP5 mRNA levels remain high in the anterodorsal nucleus, ventral subiculum, and dentate gyrus. Thus, the IGF system, represented by IGF-I or IGFBP5, demonstrates a pervasive presence throughout the limbic as well as sensory and cerebellar projection systems.

The IGF system constellation is most definitively characterized in the developing cerebellar cortex (diagrammed in Fig. 9). IGF-I is localized in Purkinje cells and IGFBP2 in Bergmann glial cells. The timing of IGF-I and IGFBP2 gene expression in these particular cells parallels the appearance and disappearance of the external granule cell layer, commencing around the time of birth and receding by P20 (Bondy, 1991; Lee et al., 1992b). IGFBP5 mRNA is localized in germinal cells of the external granule cell layer, in laminar apposition to Purkinje dendrites and Bergmann radial fibers. IGFBP5 gene expression in these cells is correlated with their proliferative index. Perinatally, all the cells of external granule cell layer appear immature and demonstrate DNA synthesis, and all express IGFBP5 mRNA, but by a few days after birth, proliferating cells are found only in the most superficial layer, while cells in the deeper layers exhibit morphological signs of differentiation and begin the process of migration through the molecular layer (Fujita et al., 1966). The postmitotic granule cells of the deep layer of the external zone and cells migrating through the molecular layer do not demonstrate IGFBP5 mRNA, but the more external cells in the germinal zone do. IGF-I immunoreactivity is abundant in the molecular layer of the developing cerebellar cortex (Andersson ct al., 1988). It is not detected in the most external cells of the external granular cell layer but is found in cells of the deeper zone and in migrating granule cells. This finding suggests that expression of IGFBP5 by cells in the external zone may prevent the receptor-mediated internalization of IGF-I released from Purkinje dendrites. IGF-I immunoreactivity is also localized in Bergmann radial fibers, suggesting that expression of IGFBP2 is not incompatible with internalization (after colchicine, it is detected only in Purkinje cells; Andersson et al., 1988). Not shown in the diagram is the fact that IGF-I receptor mRNA is detected in all the cell types present in the developing cerebellar cortex (Bondy et al., 1992a).

IGFBP5 mRNA is localized in forebrain ventricular and subventricular germinal zones during a time in which these zones give rise to olfactory granule cells in a pattern analogous to that seen in the secondary germinal zone in the cerebellar cortex. IGFBP5 mRNA is detected in cells in the germinal zone but not in postmitotic, migratory granule cells on their way into the olfactory bulb and not in young granule cells in the olfactory bulb. Later, in both the olfactory bulb and cerebellar cortex (and dentate gyrus), mature granule cells display low levels of IGFBP5 mRNA.

Finally, IGFBP5 mRNA is expressed in some glial cell populations. It is localized in cells dispersed throughout the cere-

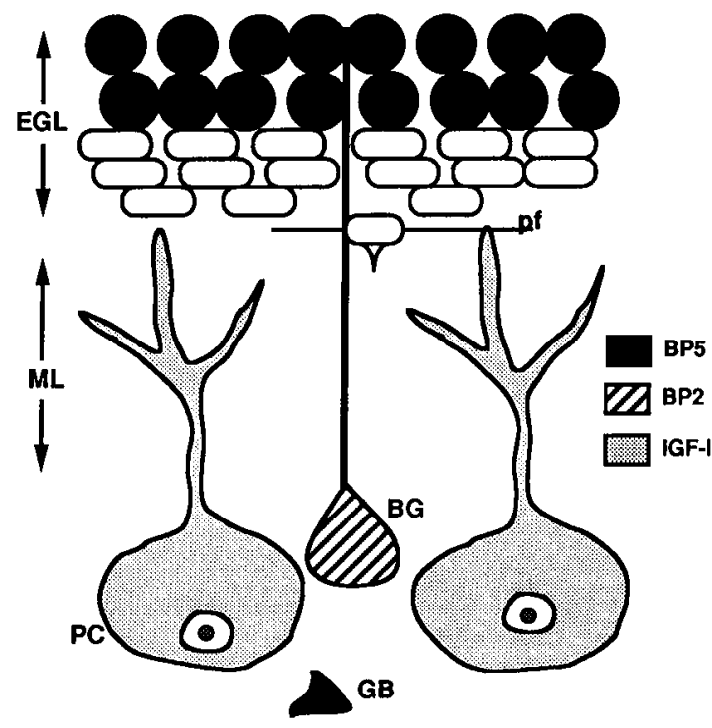

Figure 9. Diagrammatic representation of IGF system gene expression in the developing cerebellar cortex. $B G$, Bergmann glial cell; $E G L$, external granule cell layer; $G B$, glioblast; $M L$, molecular layer; $P C$, Purkinje cell; $p f$, parallel fiber.

bellar cortex from before birth to about P12. Since migration from the external germinal zone does not begin until a few days after birth (Fujita et al., 1966), these cells must have originated from periventricular germinal zones and thus are likely to be glial precursor cells (cerebellar neurons other than Purkinje cells arise from the external germinal zone). IGFBP5 mRNA is also present in cells localized in forebrain white matter tracts, most abundantly in the olfactory nerve. Given this distribution, it is likely that these IGFBP5-expressing cells are oligodendrocytes or oligodendrocyte precursors; future studies employing immunological markers will be necessary to identify more clearly the IGFBP5-expressing cells of the cerebellar plate and white matter zones.

The striking spatiotemporal correlation between IGF-I and IGFBP 2 and -5 gene expression in the developing brain suggests that these IGFBPs are important determinants of IGF-I action in CNS maturation. As far as is known, IGF-I and -II are secreted constitutively and there is no evidence for packaging of IGFs into specialized secretory vesicles that would serve to store or transport the peptides to targeted release sites. Analysis of available immunocytochemical data coupled with our in situ hybridization results suggests that IGF-I is released from neuronal soma and processes close to synthesis sites. IGF-I receptor gene expression is very widespread throughout the CNS from earliest development, in a pattern that appears to be constitutive (Bondy et al., 1992a; Bondy and Lee, 1993). Given the apparent lack of spatiotemporal focus of IGF action at the level of secretion and receptor expression, the expression of specific IGFBPs by different cells types in the vicinity of IGF-I-producing neurons may serve to target or quench IGF action with respect to these sites, thus adding a laycr of regulation operative in the extracellular space between the site of secretion and reception.

\section{Appendix}

Iist of Abbreviations

ad anterodorsal nucleus of the thalamus

AH Ammon's horn

al anterior lobe of the pituitary 


$\begin{array}{ll}\text { am } & \text { amygdaloid nuclear complex } \\ \text { av } & \text { anteroventral nucleus of the thalamus } \\ \text { cc } & \text { corpus callosum } \\ \text { cg } & \text { cingulate cortex } \\ \text { CL } & \text { claustrum } \\ \text { cp } & \text { choroid plexus } \\ \text { dc } & \text { deep cerebellar nuclei } \\ \text { dg } & \text { dentate gyrus } \\ \text { dlg,dLG } & \text { dorsolateral geniculate } \\ \text { eg } & \text { external germinal zone } \\ \text { fp } & \text { frontoparietal cortex } \\ \text { g } & \text { gelatinosa nucleus } \\ \text { GC } & \text { granule cells } \\ \text { gl } & \text { glomerular layer } \\ \text { ig } & \text { internal granule cell layer } \\ \text { IG } & \text { induseum griseum } \\ \text { IO } & \text { inferior olive } \\ \text { ls } & \text { lateral septal nucleus } \\ \text { lv } & \text { lateral ventricle } \\ \text { m } & \text { meninges } \\ \text { mc } & \text { mitral cells } \\ \text { mg } & \text { medial geniculate nucleus } \\ \text { ml } & \text { mediolateral nucleus (of the thalamus) } \\ \text { nl } & \text { neural lobe of the pituitary } \\ \text { ON } & \text { olfactory nerve } \\ \text { pf } & \text { parafascicular nucleus } \\ \text { rs } & \text { retrosplenial cortex } \\ \text { s } & \text { subiculum } \\ \text { scn } & \text { suprachiasmatic nucleus } \\ \text { SO } & \text { superior olive } \\ \text { sp } & \text { stratum pyramidale } \\ \text { sv } & \text { subventricular zone of the lateral ventricles } \\ \text { SVZ } & \text { subventricular zone } \\ \text { VPL } & \text { ventroposterolateral nucleus } \\ \text { VPM } & \text { ventroposteromedial nucleus } \\ \text { vt } & \text { ventral tier nuclei } \\ \text { VZ } & \text { ventricular zone } \\ \text { WM } & \text { white matter } \\ & \end{array}$

\section{References}

Andersson IK, Edwall D, Norstedt G, Rosell B, Skottner A, Hansson H-A (1988) Differing expression of insulin-like growth factor I in the developing and adult rat cerebellum. Acta Physiol Scand 132: 167-173.

Bar RS (1990) Transcapillary permeability and subendothelial distribution of endothelial and amniotic fluid IGF binding proteins in the rat heart. Endocrinology 127:1078-1086.

Bohannon NJ, Corp ES, Wilcox BJ, Figlewicz DP, Dorsa DM, Baskin DG (1988) Localization of binding sites for IGF-I in the rat brain by quantitative autoradiography. Brain Res 444:205-213.

Bondy CA (1991) Transient IGF-I gene expression during the maturation of functionally related central projection neurons. J Neurosci $11: 3442-3455$.

Bondy CA, Lee WH (1993) Developmental and injury-induced patterns of IGF and IGF receptor gene expression: functional implications. In: Proceedings of the NY Academy of Sciences. IGFS in the brain (Raizada M, LeRoith D, cds), in press. New York.

Bondy CA, Werner H, Roberts CT, LeRoith D (1992a) The cellular pattern of type-I IGF receptor gene expression during the maturation of the rat brain: comparison with IGF-I and IGF-II. Neuroscience 46:909-923.

Bondy CA, Bach MA, Lee WH (1992b) Mapping of brain insulin and insulin-like growth factor gene expression by in situ hybridization. Neuroprotocols 1:240-249.

Clemmons DR (1990) Insulin-like growth factor binding proteins. Trends Endocrinol Metab 1:412-417.

Fujita S, Shimada M, Nakamura T (1966) ${ }^{3} \mathrm{H}$-thymidine autoradiographic studies on the cell proliferation of the external and internal granule cell layers of the mouse cerebellum. J Comp Neurol 128:191208.

Han VKM, Lauder JM, D'Ercole AJ (1988) Rat astroglial somatomedin/insulin-like growth factor binding proteins: characterization and evidence of biological function. J Neurosci 8:3135-3143.

Haselbacher G, Humbel R (1982) Evidence for two species of insulinlike growth factor II (IGF II and "big IGF-II") in human spinal fluid. Endocrinology 110:1822-1824.

Lee WH, Clemmons JA, Bondy CA (1992a) Insulin-like growth factors in the response to cerebral ischemia. Mol Cell Neurosci 3:36-43.

Lee WH, Javedan S, Bondy CA (1992b) Coordinate expression of IGF system components by neurons and neuroglia during retinal and cerebellar development. J Neurosci 12:4737-4744.

Lee WH, Michels KM, Bondy CA (1993) Localization of insulin-like growth factor binding protein 2 mRNA during postnatal brain development: correlation with IGF-I and IGF-II. Neuroscience 53:251265.

Lesniak MA, Hill JA, Kiess W, Rojeski M, Pert CB, Roth J (1988) Receptors for IGF-I and -II: autoradiographic localization in rat brain and comparison to receptors for insulin. Endocrinology 123:20892099.

Marks JL, Portc D, Baskin DG (1991) Localization of type I IGF receptor mRNA in the adult rat brain by in situ hybridization. Mol Endocrinol 5:1158-1168.

Ocrant I, Fay CT, Parmelee JT (1990) Characterization of insulin-like growth factor binding proteins produced in the rat central nervous system. Endocrinology 127:1260-1267.

Olson JA, Shiverick KT, Ogilvie S, Buhi WC, Raizada MK (1991) Developmental expression of rat insulin-like growth factor binding protein-2 by astrocytic glial cells in culture. Endocrinology 129:10661074.

Rechler MM, Brown AL (1992) Insulin-like growth factor binding proteins: gene structure and expression. Growth Regul 2:55-68.

Roghani M, Lassarre C, Zapf J, Povoa G, Binoux M (1991) Two insulin-like growth factor (IGF)-binding proteins are responsible for the selective affinity for IGF-II of cerebrospinal fluid binding protcins. $\mathrm{J}$ Clin Endocrinol Metab 73:658-666.

Rosenfeld RG, Lamson GL, Oh Y (1990) Insulin like growth factor binding proteins. Rec Prog Horm Res 46:99-163.

Sara VB, Hall K, von Holtz H, Humbel R, Sjogren B, Wetterberg L (1982) Evidence for the presence of specific receptors for IGF-I and IGF-II and insulin throughout the adult human brain. Neurosci Lett 34:39-44.

Tseng LY-H, Brown AL, Yang YW-H, Romanus JA, Orllowski CC, Raylor T, Rechler MM (1989) The fetal rat binding protein for insulin-like growth factors is expressed in the choroid plexus and cerebrospinal fluid of adult rats. Mol Endocrinol 3:1559-1568.

Werther GA, Hogg A, Oldfield BJ, McKinley MJ, Figdor R, Mendelsohn (1989) Localization and characterization of IGF-I receptors in rat brain and pituitary gland using in vitro autoradiography and computerized densitometry: distinct distribution from insulin receptors. J Endocrinol 1:369-377.

Wood TL, Brown AL, Rechler MM, Pintar JE (1990) The expression pattern of an insulin-like growth factor (IGF)-binding protein gene is distinct from IGF-II in the midgestational rat embryo. Mol Endocrinol 4:1257-1263.

Zhou J, Bondy CA (1993) Anatomy of the human ovarian IGF system. Biol Reprod 48:467-482. 